\title{
Brief Communication: On the source characteristics and impacts of the magnitude 7.2 Bohol earthquake, Philippines
}

\author{
A. M. F. Lagmay ${ }^{1,2}$ and R. Eco ${ }^{1,2}$ \\ ${ }^{1}$ National Institute of Geological Sciences, University of the Philippines, C. P. Garcia corner Velasquez street, U. P. Diliman, \\ 1101 Quezon City, Philippines \\ ${ }^{2}$ Department of Science and Technology (DOST) - Project NOAH, Univeristy of the Philippines, C. P. Garcia corner \\ Velasquez street, U. P. Diliman, 1101 Quezon City, Philippines
}

Correspondence to: A. M. F. Lagmay (mlagmay@noah.dost.gov.ph, mlagmay@nigs.upd.edu.ph)

Received: 3 November 2013 - Published in Nat. Hazards Earth Syst. Sci. Discuss.: 18 March 2014

Revised: 14 August 2014 - Accepted: 27 August 2014 - Published: 22 October 2014

\begin{abstract}
A devastating earthquake struck Bohol, Philippines, on 15 October 2013. The earthquake originated at $12 \mathrm{~km}$ depth from an unmapped reverse fault, which manifested on the surface for several kilometers and with maximum vertical displacement of $3 \mathrm{~m}$. The earthquake resulted in 222 fatalities with damage to infrastructure estimated at USD 52.06 million. Widespread landslides and sinkholes formed in the predominantly limestone region during the earthquake. These remain a significant threat to communities as destabilized hillside slopes, landslide-dammed rivers and incipient sinkholes are still vulnerable to collapse, triggered possibly by aftershocks and heavy rains in the upcoming months of November and December. The most recent fatal temblor originated from a previously unmapped fault, herein referred to as the Inabanga Fault. Like the hidden or previously unmapped faults responsible for the 2012 Negros and 2013 Bohol earthquakes, there may be more unidentified faults that need to be mapped through field and geophysical methods. This is necessary to mitigate the possible damaging effects of future earthquakes in the Philippines.
\end{abstract}

\section{Introduction}

On 15 October 2013 at 08:12 LT (local time), a magnitude $\left(M_{\mathrm{W}}\right) 7.2$ earthquake struck the island of Bohol (Phivolcs, 2013c) in the central Philippines region of Visayas (Fig. 1). The earthquake's focus was $12 \mathrm{~km}$ deep with its epicenter located at $9.86^{\circ}$ latitude and $124.07^{\circ}$ longitude, $6 \mathrm{~km}$ southwest of Sagbayan, Bohol (Phivolcs, 2013b). Initial and pre- liminary reports by the USGS sent a few minutes after the earthquake had the temblor pegged at magnitude $\left(M_{\mathrm{w}}\right) 7.2$ occurring at 08:12 LT with the epicenter $2 \mathrm{~km}$ south of Nueva Vida Sur, Bohol, Philippines. The USGS record on the earthquake was later revised to magnitude $\left(M_{\mathrm{w}}\right) 7.1$ with focal depth of $20 \mathrm{~km}$. Based on preliminary reports on the earthquake intensity, ground shaking was highest at intensity VII in the Philippine Earthquake Intensity Scale (PEIS) (Phivolcs, 2008) felt at Tagbilaran, Bohol. In other places, ground-shaking effects registered intensity VI in Hinigaran, Negros Occidental, intensity V in Iloilo City and La Carlota, intensity IV in Masbate City, Roxas City, San Jose, Culasi, Antique, Guihulngan, Negros Oriental and intensity III in Davao City (Phivolcs, 2013b). Later reports coming from near the epicenter of the quake show images of centuriesold churches flattened to the ground and collapsed buildings (Fig. 2) giving rise to intensities measuring VIII or higher. To date (3 November 2013), the National Disaster Coordinating Council (NDRRMC) has reported 222 fatalities, 976 injured and 8 missing. A total of 73002 houses were damaged, 14512 of which were totally destroyed, with 58490 houses partially affected. Out of the 41 bridges affected by the earthquake, 3 are still not passable while 2 out of the 18 roads damaged are still impassable (NDRRMC, 2013). The total estimated cost of the damage to infrastructure is PHP 2.257 million (USD 52.06 million). Landslide occurrences were recorded in 25 villages in Bohol and 13 villages in Cebu (NDRRMC, 2013) with reports of landslides damming rivers, raising fears of possible floods. 

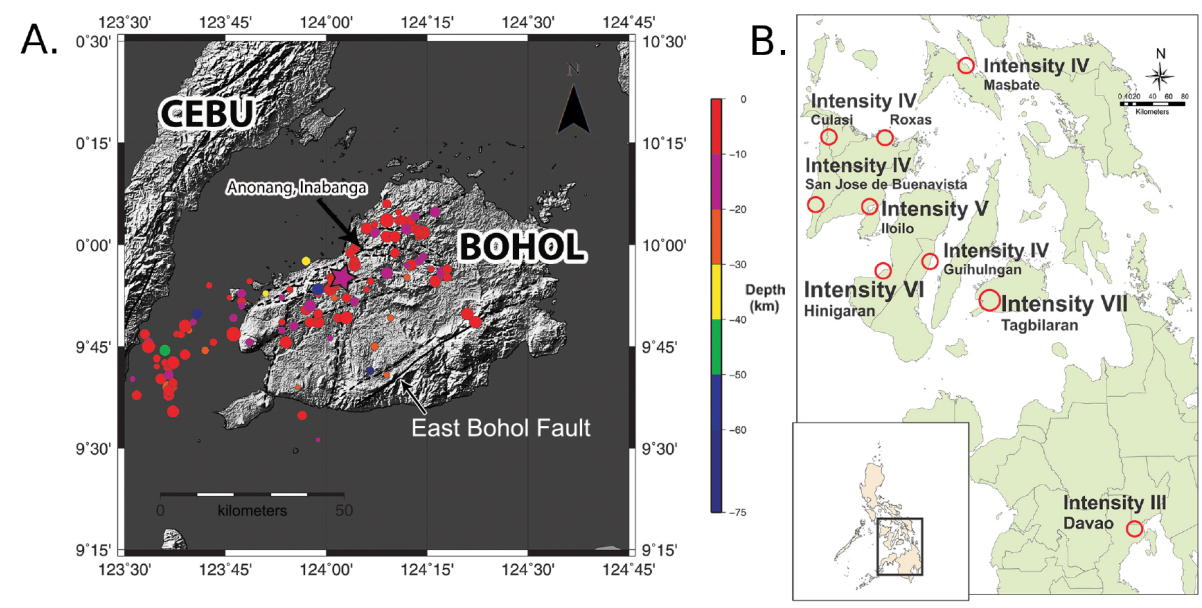

Figure 1. Earthquake (a) epicenters in Bohol and their corresponding depth according to Phivolcs as of 20 October 2013 (online list of recent earthquakes). The purple star indicates the epicenter of the $M_{\mathrm{W}}=7.2$ earthquake with a depth $12 \mathrm{~km}$, (b) intensities in Bohol and adjacent cities and municipalities. Dashed black lines are lineaments in the shaded relief image of the island of Bohol, while the solid black line in the south is the East Bohol Fault.

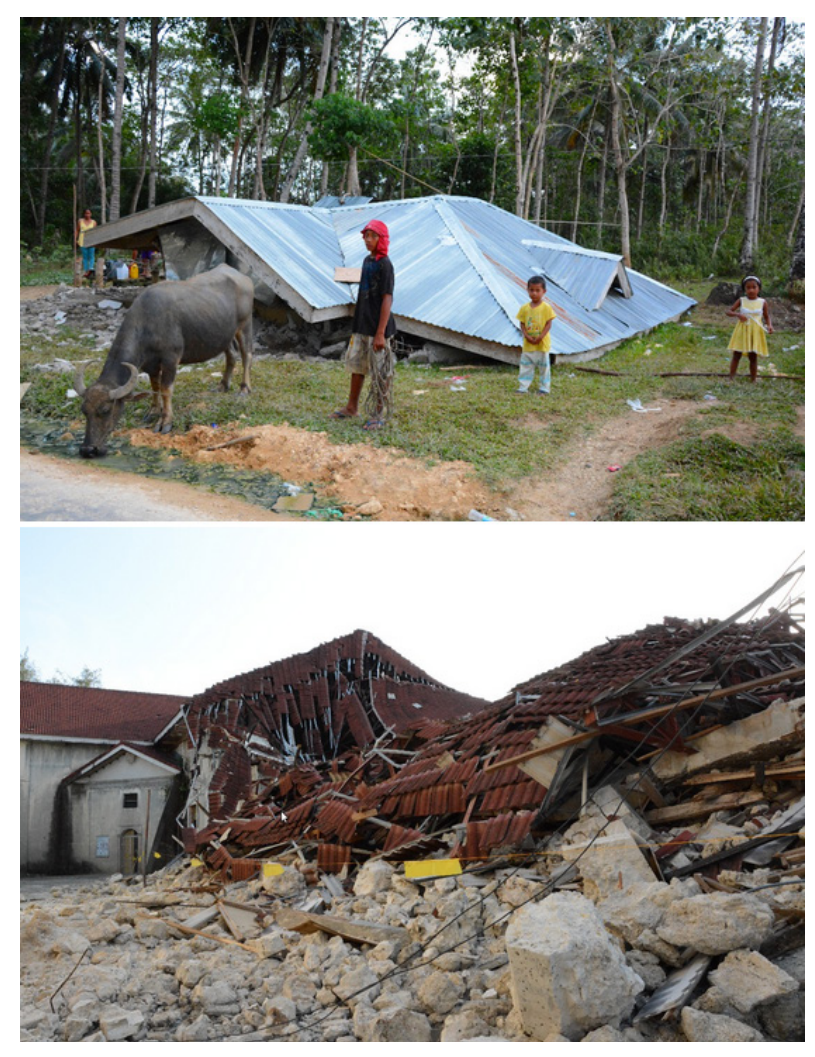

Figure 2. Images of the disaster: top - collapsed house in Sagbayan municipality, Bohol. Bottom - Inabanga church in Bohol. Photo credit: A. M. F. Lagmay (photo taken on 23 October 2013).

As of 04:00 LT, 3 November 2013, 3198 aftershocks have been recorded by the Philippine Institute of Volcanology and Seismology, 94 of which were felt (NDRRMC, 2013). The earthquake epicenters plot in a northeast-southwest trend spanning approximately $100 \mathrm{~km}$ from mainly inland to offshore areas southwest of the island of Bohol (Fig. 1a). Focal mechanism solutions generated by the Global Centroid Moment Tensor (CMT) project (Dziewonski et al., 1981; Ekstrom et al., 2012), which depict the type of slip movement of the earthquake fault, show a reverse fault (dominant vertical motion) with a slight right lateral strike-slip component for the main shock (Fig. 3). Two significantly large aftershocks recorded at 4:36 p.m. (local time) on the day of the main shock had reverse and strike-slip focal mechanisms, respectively. The $M_{\mathrm{s}}=5.9\left(M_{\mathrm{w}}=5.7\right)$ earthquake was a reverse fault-related aftershock while the $M_{\mathrm{s}}=5.5\left(M_{\mathrm{w}}=5.6\right)$ earthquake was related to strike-slip fault movement (Fig. 3).

Here we describe the tectonic setting of the Philippines, the known active faults in the central Philippines region and past earthquakes that have affected Bohol. We then make an initial interpretation of the source mechanisms of the earthquake and propose a name for the newly mapped fault responsible for devastating the island of Bohol. This document serves as a quick and accessible reference for the $M_{\mathrm{w}}=7.2$ event, and the possible consequent hazards that may have been generated. These include destabilized hillside slopes, landslide-dammed rivers, and incipient sinkholes, which need to be identified and addressed before heavy rains come in the remaining months of the year.

\section{Tectonic framework of the Philippines}

\subsection{Major tectonics features}

The Philippine archipelago is a mature island arc that is at present being accreted to the eastern margin of the Eurasian Plate. It is composed of a complex mixture of terranes (Encarnación, 2004) formed through plate interaction of the 


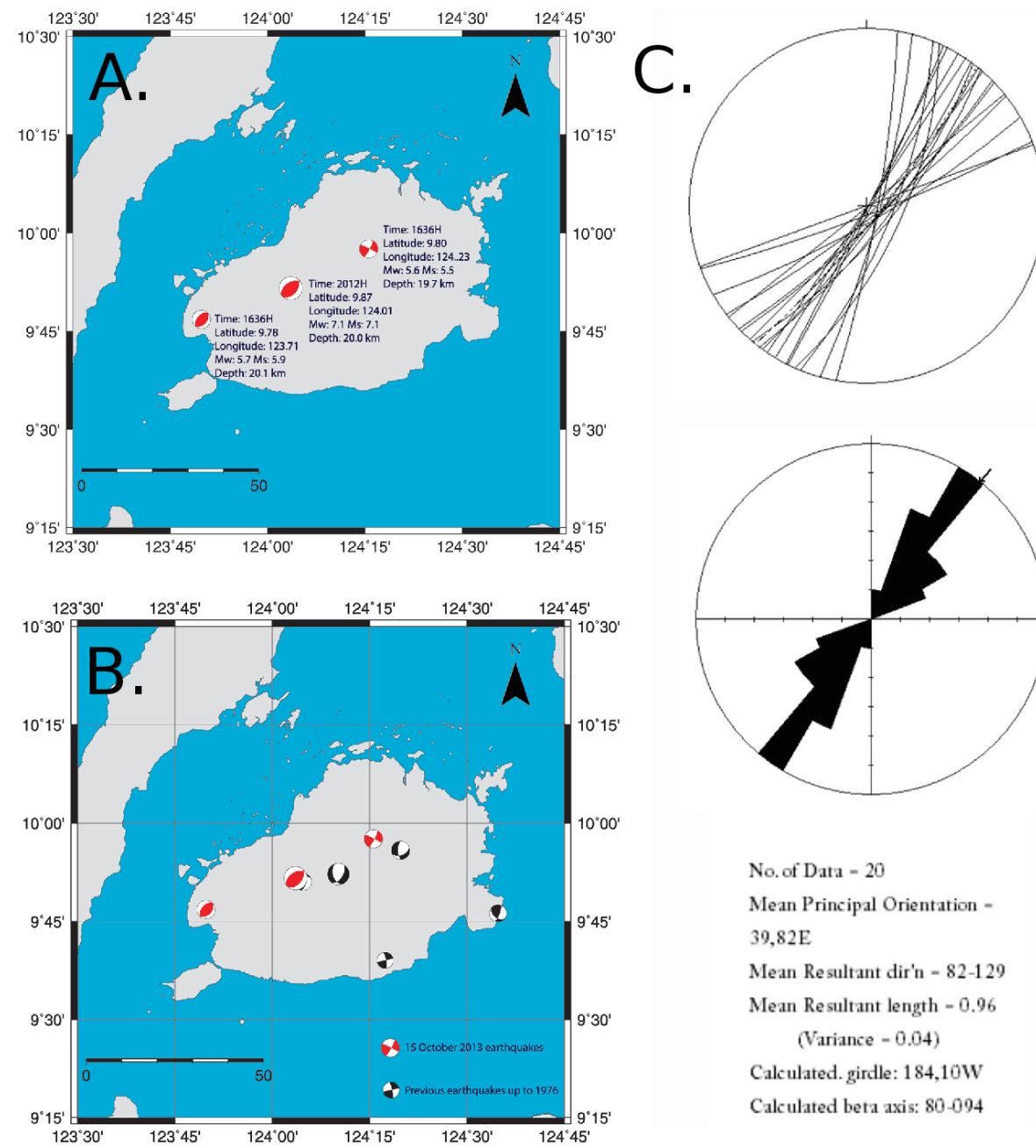

Figure 3. Focal mechanism solution of earthquakes recorded on (a) 15 October 2013 in Bohol and (b) prior to the $M_{\mathrm{W}}=7.2$ Bohol earthquake (black beach balls). (c) Stereo plot and rose diagram of the fault that generated the $M_{\mathrm{W}}=7.2$ as measured in Bohol. The mean principal orientation of the fault based on 20 measurements of its plane is $39^{\circ} \mathrm{NE}$ dipping $82^{\circ} \mathrm{SE}$.

Philippine Sea plate, Eurasian Plate and the Indo-Australian Plate (Fig. 4).

The entire archipelago is characterized by a system of subduction zones, collision zones, and wrench faults (Fig. 4). The actively deforming region of the Philippines is a zone known as the Philippine Mobile Belt (PMB) (Gervasio, 1967), bound on both sides by subduction zones. Westdipping subduction is marked on the Pacific seafloor by the Philippine Trench. Towards the north, the Philippine Trench connects to the Polilio Fault and the East Luzon Trough, a seafloor depression which marks a clogged subduction zone (Lagmay et al., 2009). Generally east-dipping subduction zones are underneath the Manila, Negros, Sulu, and Cotabato trenches. In between these west- and east-dipping subduction zones is the left-lateral Philippine Fault (Allen, 1962), which straddles the entire length of the PMB. There are many active faults in the archipelago, but the closest active faults in the Bohol region are the Cebu lineaments, central Negros
Fault, Panay Fault and the western Mindanao Fault. The tectonic structures in the Philippines accommodate the stress imparted by the ongoing northwest movement of the Philippine Sea plate towards Eurasia (Huchon, 1986). Southwest of the PMB is the Palawan-Mindoro block, an aseismic region of the Philippines of continental affinity (Holloway, 1982).

The trenches in the east and west of the archipelago are major sites of seismicity and where marginal basins surrounding the Philippines are consumed. The South China Sea, Sulu Sea and the Celebes Sea basins subduct along the east-dipping Manila, Negros and Cotabato trenches, respectively. The Sulu Trench is the locus where the Sulu Sea is consumed while the Philippine Trench is the site where the Philippine Sea plate subducts (Rangin and Silver, 1991; Rangin, 1991; Aurelio, 2000). 


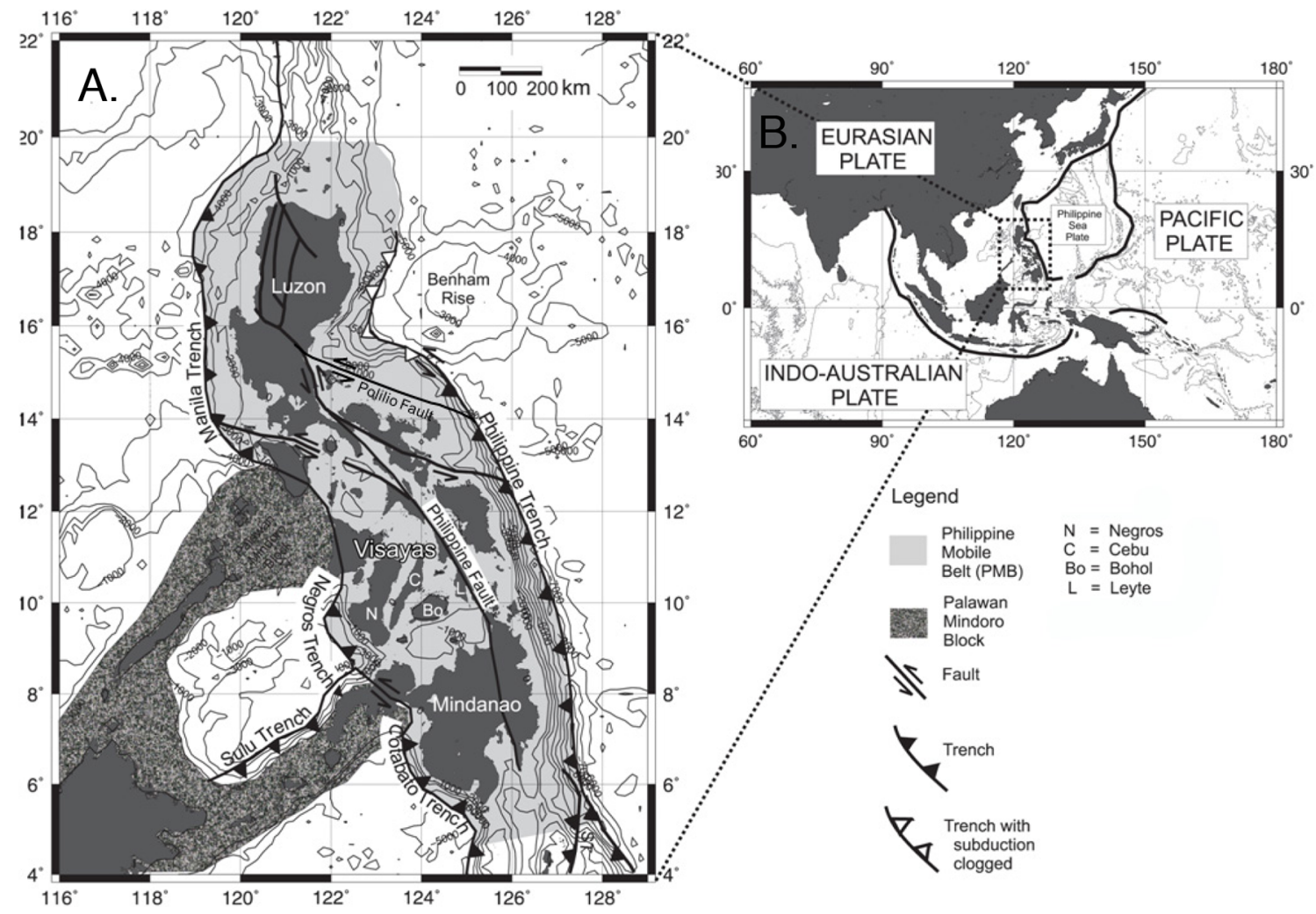

Figure 4. (a) Map showing the main plates surrounding the Philippine archipelago. (b) Major tectonic features of the Philippines. The gray shaded area is the Philippine Mobile Belt (PMB) of Gervasio (1967). The stippled gray shaded area is the Palawan-Mindoro continental block. Black triangles along the trench represent the dip direction of subduction. White triangles represent a clogged subduction zone (East Luzon Trough).

\subsection{Faults in Bohol and nearby islands}

According to Philippine Institute of Volcanology and Seismology (Phivolcs), the only mapped active fault in Bohol prior to the 15 October 2013 earthquake is the East Bohol Fault (Figs. 1 and 5). This fault is a NE-SW-trending structure that may be associated with the Alicia Thrust Fault (Besana-Ostman et al., 2011), described by the Bureau of Mines and Geosciences (BMG) in 1982. Most portions of the Alicia Thrust Fault are overlain by Miocene to recent limestones and do not exhibit deformation, which suggests that it has been inactive for a long time (BMG, 1982). Other NESW-trending faults near Bohol are the central Negros Fault and Cebu lineaments (Fig. 5).

On 6 February 2012, a $M_{\mathrm{b}}=6.9$ crustal earthquake with a depth of $10 \mathrm{~km}$ shook Negros and Cebu islands (Phivolcs, 2013a) which left 51 people dead and caused heavy damage to infrastructure (NDRRMC, 2012). The main shock and ensuing aftershocks of the fatal February 2012 earthquakes have epicenters on the eastern coast of Negros Oriental (Phivolcs, 2013a). The focal mechanism solution of the 2012 Negros main shock is oriented NNE and attributed to a blind thrust fault (Aurelio, 2012; ABS-CBN, 2012). None of the 2012 Negros earthquakes were officially linked to the central Negros Fault, although there are reports that the fault responsible for the Negros earthquake was already identified prior to the 2012 earthquake event (SunStar, 2012). Moreover, a $75 \mathrm{~km}$ long, NNE-oriented ground rupture associated with the $M_{\mathrm{b}}=6.9$ February 2012 Negros temblor on the eastern side of Negros island was reported in a conference. The authors describe a ground rupture length and scarp heights consistent with the earthquake's magnitude and sense of movement based on focal mechanism solutions (Rimando et al., 2013).

In the geodynamic context, all the NE-trending faults, including the central Negros Fault, Cebu lineaments, East Bohol Fault, the blind thrust faults and the reported $75 \mathrm{~km}$ long ground rupture in the east coast of the island of Negros are associated with a compressional stress regime. These compressional faults are located in between the Negros Trench and the left-lateral Philippine Fault (Fig. 4), which has a slip rate of about $2-2.5 \mathrm{~cm} \mathrm{yr}^{-1}$ in its central segment (Barrier et al., 1991). The kinematics of these NE-SW compressional faults are consistent with GPS data that describe NW-SE shortening of the Visayas block at a rate of about $1.3 \mathrm{~cm} \mathrm{yr}^{-1}$ (Rangin et al., 1999). 


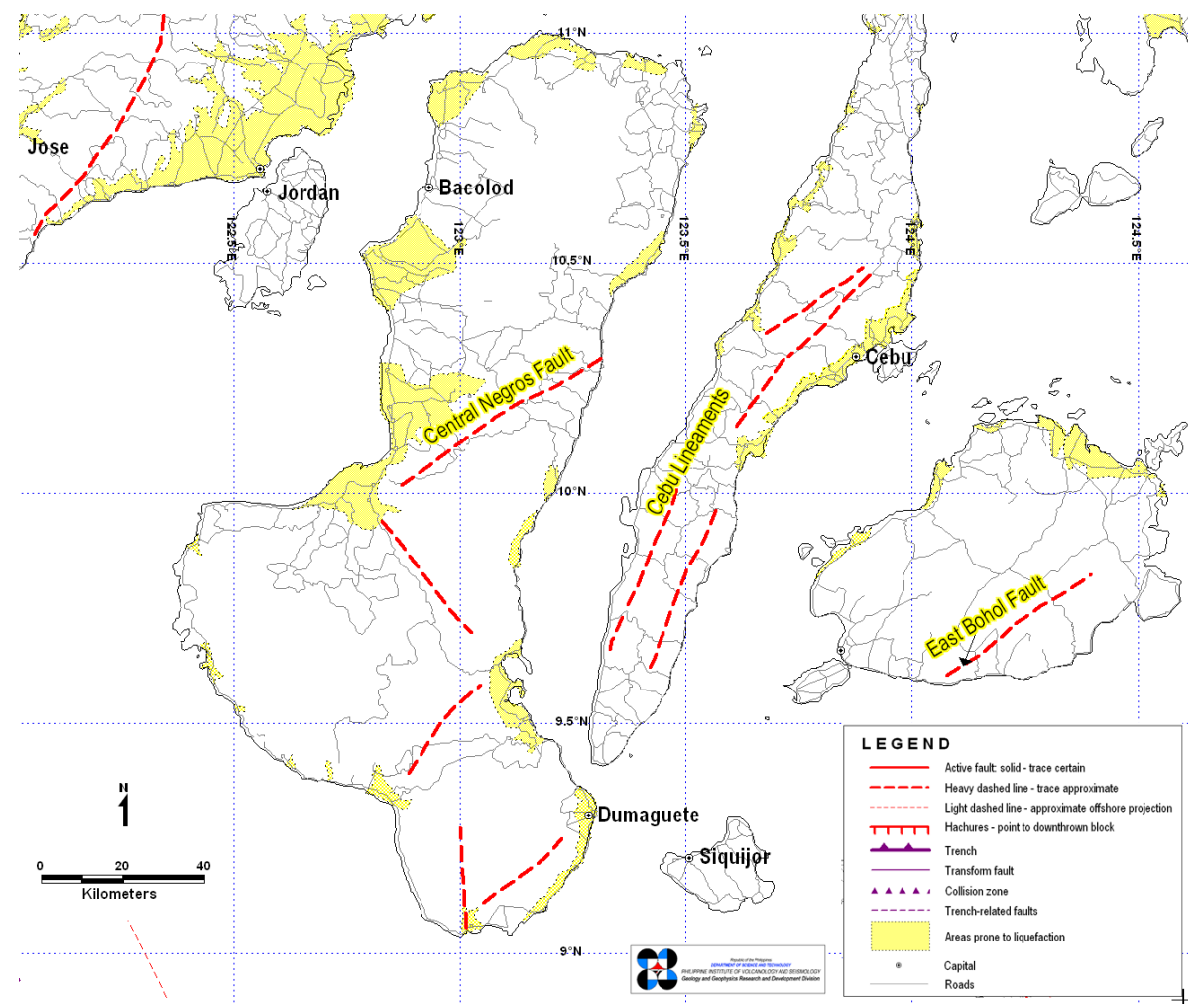

Figure 5. Active fault map of Bohol and nearby islands according to Phivolcs.

\section{Past earthquakes}

Relative to other regions within the Philippine Mobile Belt, Bohol is not as active in terms of large shallow focus earthquakes. Most of the earthquake epicenters that plot in Bohol are related to deep focus earthquakes associated with the eastward subduction of the Philippine Sea plate. However, damaging crustal earthquakes in Bohol have also occurred in recent years. These are the $1990 M=6.8$ earthquake and the $1996 M=5.6$ Bohol earthquakes.

The East Bohol Fault was responsible for generating the $M=6.8$ Bohol earthquake on 8 February 1990, which generated tsunamis as high as $2 \mathrm{~m}$ and significant inundation in the southeastern coast of the island. The epicenter of the 1990 Bohol earthquake was located $17 \mathrm{~km}$ east of Tagbilaran City with intensities reaching VIII on the Rossi-Forel scale in the town of Jagna, Duero and Guindulman in Bohol (Umbal et al., 1990). The temblor exacted six fatalities with more than 200 injured. Approximately 46000 people were displaced with at least 7000 rendered homeless. Damage to property for the 1990 Bohol earthquake was estimated at PHP 154 million (Phivolcs, 1996).

The $M=5.6$ earthquake struck on 27 May 1996 and was centered in the municipality of Clarin, Bohol. Damage brought by the 1996 earthquake was confined to poorly built structures and/or old wooden, masonry, limestone walls of houses and buildings, generally due to ground shaking. There were no reports and observations attributed to other earthquake hazards such as liquefaction, ground subsidence, landslide and any other geologic ground disturbances during the 1996 Bohol earthquake (Phivolcs, 1996).

\section{Earthquake source}

When the 2013 earthquake happened, the only mapped active fault on the island of Bohol is the East Bohol Fault (Phivolcs, 2000). It was originally believed to be the source of the $M_{\mathrm{w}}=7.2$ earthquake, but it would appear based on the locus of earthquake epicenters and initial field reports that an unmapped fault or faults about $20-25 \mathrm{~km}$ north of the East Bohol Fault were responsible for the $M_{\mathrm{w}}=7.2$ earthquake and most of the aftershocks (Fig. 1a). Lineament analyses of digital topography show northeast-southwest-trending structures cutting across the northern portion of the island of Bohol, passing through several municipalities. In the village of Anonang, municipality of Inabanga, there were several aftershocks recorded. Displacement of originally gently sloping to flat ground formed a northeast- to southwesttrending scarp up to $3 \mathrm{~m}$ high and extends more than $5 \mathrm{~km}$ long (Fig. 6). In some areas, the scarp was only about $0.4 \mathrm{~m}$ high. Eyewitnesses recount heaving of the ground and development of the scarp right before them sometime between 08:00 and 08:30 LT. Some noted the upheaval of the gently 


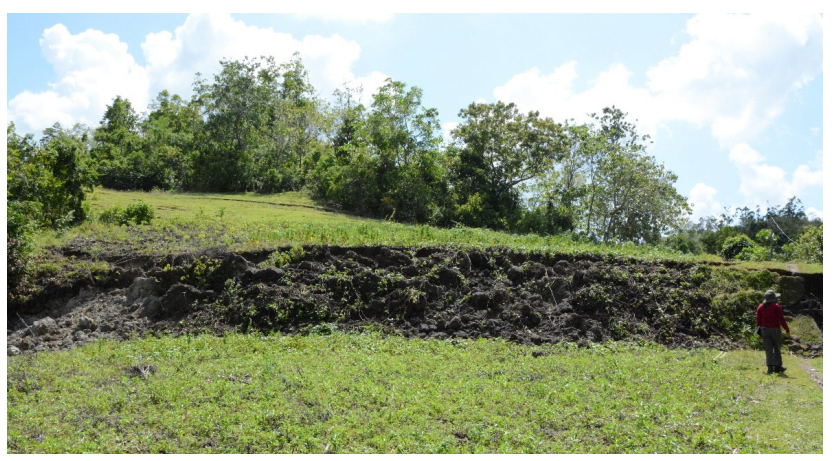

Figure 6. Formerly gently sloping ground split through reverse faulting into an upthrown block and lower block forming a $3 \mathrm{~m}$ high scarp that extends for several kilometers. Photo credit: A. M. F. Lagmay (photo taken on 23 October 2013).

sloping grounds at the foot of hilly terrain generating a vertical wall over the span of about a minute. The exact length measurement of the scarp due to reverse faulting is currently being determined in the field and through lineament mapping using high-resolution imagery.

In the worldwide database of earthquakes, a $3 \mathrm{~m}$ displacement of a fault approximately corresponds to a magnitude 7.2 earthquake (Wells and Coppersmith, 1994). Based on this, the fault seen very well exposed in Barangay Anonang, Inabanga, is most likely to have been responsible for the $M_{\mathrm{w}}=7.2$ earthquake in Bohol. This earthquake triggered thousands of aftershocks. However, the trend of the epicenters of these earthquakes, which span 90-100 km and reach nearly the southern part of Cebu island, does not exactly follow the orientation of the fault trace found in Inabanga municipality (see Fig. 1). The reverse fault in Inabanga also does not account for the strike-slip focal mechanism solution of an earthquake recorded in the afternoon of the devastating Bohol event (see Fig. 3a). There are other lineaments found in the northern part of Bohol, and they could correspond to a fault system defined by the large number of earthquakes triggered by the main shock. These too must be mapped out in detail when possible.

The nomenclature of newly discovered faults or geological formations for that matter is normally based on where they are best exposed and described. Because Inabanga municipality is located where the reverse fault was first seen $\left(10^{\circ} 0^{\prime} 55.62^{\prime \prime} \mathrm{N}, 124^{\circ} 8^{\prime} 5.75^{\prime \prime} \mathrm{E}\right)$ and archetypal for the fault that generated the fatal $M_{\mathrm{W}}=7.2$ earthquake of Bohol, we propose to name the fault as the Inabanga Fault. This also would prevent complications in the future should any other active faults be discovered and mapped in the large area affected by the temblor in northern Bohol.

The person who sent the first report that led to the discovery of the Inabanga Fault was Mr. Howie Severino, a news anchor of GMA channel 7. He sent cell phone multi-media messages to the author on 19 October 2013. After interpreting the images and descriptions sent by Mr. Severino, he was immediately advised by the authors to contact Phivolcs regarding his finding. By 21 November 2013, a team of geologists from Phivolcs confirmed the newly formed scarp as the previously unknown fault that triggered the $M_{\mathrm{W}}=7.2$ earthquake (Severino, 2013).

\section{Discussion and conclusions}

Follow-up work is necessary to adequately describe the $M_{\mathrm{w}}=7.2$ earthquake and understand the recurrence interval of movement of the fault which generated the strongest earthquakes in Bohol in 2013. This article is the initial documentation, prepared and submitted 2 weeks after the October 2013 Bohol temblor. Currently, numerous research activities are underway from local and foreign scientists working with the National Institute of Geological Sciences, University of the Philippines and Phivolcs. Research work, both planned and ongoing, includes the following: (1) pre- and post-earthquake event field analysis aided by high-resolution lidar and IfSAR digital terrain models; (2) paleoseismic trenching study of the Inabanga Fault; (3) microtectonic analysis of the exposed fault in Inabanga, Bohol; (4) seismic reflection survey of the Inabanga Fault, and (5) analysis of capable faults in Bohol and nearby islands.

The Bohol earthquake is a devastating event that emanates from one of the many faults that straddle the Philippine islands. There are many active faults that have been mapped and are potential sites for devastating earthquakes. Many active faults listed by Phivolcs are near urban centers, populated by millions of people. Metro Cebu, which is the second-most populous metropolitan area in the Philippines after Metro Manila, came out relatively unscathed with only 12 deaths compared to the 222 fatalities on the island of Bohol where the earthquake emanated. A year and a half earlier, on 6 February 2012, a shallow focus $M_{\mathrm{b}}=6.9$ earthquake generated by an unmapped thrust fault and referred to as a blind fault struck the island of Negros immediately west of Cebu. That earthquake caused considerable damage killing 51 people with 62 missing and presumed dead (NDRRMC, 2012). Attendant hazards formed in the predominantly limestone region remain a significant threat to communities as destabilized hillside slopes, landslide-dammed rivers and incipient sinkholes are still vulnerable to collapse, triggered possibly by aftershocks and heavy rains in the upcoming months of November and December.

The most recent fatal temblor originated from a previously unmapped fault which devastated the island of Bohol. Like the hidden or previously unmapped faults responsible for the 2012 Negros and 2013 Bohol earthquakes, there may be more unidentified faults that need to be mapped through field and geophysical methods. This is necessary to address the possible damaging effects associated with fault activity. These recent events are a wake-up call for all residents of the Philippines to brace for possible earthquakes that may strike the country elsewhere, anytime. 
Acknowledgements. We wish to acknowledge the DOST-Project Nationwide Operational Assessment of Hazards (NOAH) DREAM component program for the $10 \mathrm{~m}$ resolution DEM of the island of Bohol and for providing fieldwork funds. We also thank Richard Ybanez for plotting the initial version of the Bohol earthquake epicenters and focal mechanism solutions using GMT.

Edited by: O. Katz

Reviewed by: M. Blackett and five anonymous referees

\section{References}

ABS-CBN: Phivolcs: Negros quake caused by "blind fault", http://www.abs-cbnnews.com/video/-depth/02/06/12/ phivolcs-negros-quake-caused-blind-fault, last access: 20 October 2013, 2012.

Allen, C.: Circum-Pacific faulting in the Philippines-Taiwan region, J. Geophys. Res., 67, 4795-4812, 1962.

Aurelio, M.: Shear partitioning in the Philippines: constraints from Philippine fault and global positioning data, Island Arc., 9, 584597, 2000.

Aurelio, M.: Disaster from the unknown, http://opinion.inquirer. net/24249/disaster-from-the-unknown (last access: 21 October 2012), 2012.

Barrier, E., Huchon, P., and Aurelio, M.: Philippine Fault: a key to Philippine kinematics, Geology, 19, 32-25, 1991.

Besana-Ostman, G., Ando, M., Daligdig, J., Abigania, M., Talisic, J., Evangelista, N., Listanco, E., and Solidum, R.: The 1990 Bohol earthquake, Tsunami observations and effects at Bohol Island, J. Tsunami Int., 3, 78-93, 2011.

BMG: Geology and Mineral Resource of the Philippines, vol. 1, Bureau of Mines and Geosciences, Manila, 1982.

Dziewonski, A., Chou, T., and Woodhouse, J. H.: Determination of earthquake source parameters from waveform data for studies of global and regional seismicity, J. Geophys. Res., 86, 2825-2852, 1981.

Ekstrom, G., Nettles, M., and Dziewonski, A. M.: The global CMT project 2004-2010: Centroid-moment tensors for 13,017 earthquakes, Phys. Earth Planets Inter., 200-201, 1-9, 2012.

Encarnación, J.: Multiple ophiolite generation preserved in the northern Philippines and the growth of an island complex, Tectonophysics, 392, 103-130, 2004.

Gervasio, F.: Age and nature of orogenesis in the Philippines, Tectonophysics, 4, 379-402, 1967.

Holloway, N.: The stratigraphic and tectonic relationship of Reed Bank, north Palawan and Mindoro to the Asian mainland and its significance in the evolution of the South China Sea, Assoc. Am. Petrol. Geol. Bull., 66, 1357-1383, 1982.

Huchon, P.: Comment on the "Kinematics of the Philippine Sea Plate", Tectonics, 5, 165-168, 1986.

Lagmay, A., Tejada, L. G., Pena, R. E., Aurelio, M., Davy, B., David, S., and Billedo, E.: New Definition of Philippine Plate Boundaries and Implications to the Philippine Mobile Belt, J. Geol. Soc. Philipp., 64, 17-30, 2009.
NDRRMC: Sitrep 22 re Effects of the 6.9 earthquake in Negros Oriental, National Disaster Risk Reduction and Management Council, Quezon City, Philippines, 2012.

NDRRMC: Sitrep 35 re Effects of Magnitude 7.2 Sagbayan, Bohol earthquake, National Disaster Risk Reduction and Management Council, Quezon City, Philippines, 2013.

Phivolcs: Compilation of damaging earthquakes of the Philippines - Bohol Earthquake - 27 May 1996, http://202.90.128. 66/1996BoholEQ/index-bohol96.html (last access: 21 October 2013), 1996.

Phivolcs: Active Faults of the Philippines, Map, http: //www.phivolcs.dost.gov.ph/index.php?option=com_ content $\&$ view $=$ article $\&$ id $=78 \&$ Itemid $=500024$ (last access: 22 October 2013), 2000.

Phivolcs: Phivolcs Earthquake Intensity Scale (PEIS), Online, available at: http://www.phivolcs.dost.gov.ph, 2008.

Phivolcs: Primer on the 6 February 2012 Magnitude 6.9 earthquake at Negros Oriental, http://www.phivolcs.dost.gov.ph (last access: 20 October 2013), 2013a.

Phivolcs: Primer on the 2013 Bohol earthquake, http://www. phivolcs.dost.gov.ph (last access: 20 October 2013), 2013b.

Phivolcs: Online database of Philippine earthquake epicenters, http://www.phivolcs.dost.gov.ph (last access: 25 October 2013), 2013c.

Rangin, C.: The Philippine Mobile Belt: A complex plate boundary, J. Southeast Asian Earth Sci., 6, 209-220, 1991.

Rangin, C. and Silver, E.: Neogene tectonic evolution of the Celebes-Sulu basins: new insight from leg 124 drilling, Ocean Drilling Program, in: Proceedings of the Ocean Drilling Program, Scientific Result, edited by: Silver, E., Rangin, C., and von Breymann, M., Ocean Drilling Program, College Station, TX, 1991.

Rangin, C., Pichon, X. L., Mazzotti, S., Pubellier, M., ChamotRooke, N., Aurelio, M., Walpersdorf, A., and Quebral, R.: Plate convergence measured by GPS across the Sundaland/Philippine Sea Plate deformed boundary: the Philippines and eastern Indonesia, Geophys. J. Int., 139, 296-316, doi:10.1046/j.1365246x.1999.00969.x, 1999.

Rimando, R. E.: Ground Rupture of the February 06, 2012 Negros Earthquake, in: GEOCON 2013 REPORTS, Geological Society of the Philippines, Mandaluyong, 2013.

Severino, H.: Eureka! Fault that triggered quake discovered in northern Bohol, http://tinyurl.com/m4vmpxs (last access: 21 October 2013), 2013.

SunStar: Negros fault line discovered since 2008, Online, http://www.sunstar.com.ph/cebu/local-news/2012/02/11/ negros-fault-line-discovered-2008-205628, last access: 18 October 2013, 2012.

Umbal, J., Masigla, L., Medrano, R., and Diolata, G.: Report of Investigation on the Feb. 8, 1990 earthquake in Bohol Province, Internal report, Phivolcs internal report, Quezon City, 1990.

Wells, D. and Coppersmith, K.: Maximum Surface Fault Displacement vs. Earthquake Moment Magnitude, New empirical relationships among magnitude $\mathrm{Mw}$, rupture length, rupture width, rupture area and rupture displacement, Bull. Seismol. Soc. Am., 84, 974-1002, 1994. 